\title{
Clinical Reasoning: A 69-year-old man with rare complex visual symptoms
}

Alex Vicino, MD, Olivier Rouaud, MD, Renaud Du Pasquier, MD, and Davide Strambo, MD

Neurology ${ }^{\circledR}$ 2020;95:316-320. doi:10.1212/WNL.0000000000010218
Correspondence

Dr. Vicino

alex.vicino@chuv.ch

\section{Section 1}

A 69-year-old man was admitted from the emergency department of our hospital for subacute onset of visual complaints. The evening before admission, around 10 PM, while watching TV, he experienced binocular and persistent discomposed colors in the lower left visual field (appearing both inside and outside the television screen) that did not change with the direction of gaze. He went to bed and woke up at $1 \mathrm{Am}$ for usual nocturia; then, trying to read his alarm clock, he was unable to understand what time it was despite correctly seeing the numbers. He did not report other visual difficulties at that moment. When he woke again at $3 \mathrm{Am}$, he had the impression he could not correctly define his position in space and, returning to bed, bumped into a lamp and had the feeling that his head went inside the lamp. At $5 \mathrm{AM}$, waking up again, he found he was completely blind.

The patient's medical history included chronic lymphoid leukemia, in remission at the time of admission and previously treated with cyclophosphamide and rituximab 1 year prior to admission, and then fludarabin 6 months before admission.

The patient was known to have iatrogenic hypogammaglobulinemia, treated by monthly infusions of IV immunoglobulins (last administration 1 week prior to admission). The only other chronic treatment was prophylactic trimethoprim/sulfamethoxazole 3 times a week.

On admission, the patient's blood pressure (BP) was 174/95 mm Hg. Temperature, heart rate, and cardiac, pulmonary, abdominal, and skin examinations were normal.

At the neurologic examination in the emergency department at $11 \mathrm{AM}$, the patient was awake with no evidence of cognitive dysfunction. Pupils were symmetric and normoreactive to light, without a relative afferent pupillary defect. He had no visual acuity: he could not see objects or count fingers even at short distances $(<30 \mathrm{~cm})$, but he could perceive light. Optokinetic nystagmus was absent. Fundoscopic examination was normal. Other cranial nerves appeared normal, and there were no strength, sensitivity, or coordination deficits. Reflexes were symmetric and cutaneous plantar response was flexor.

Routine laboratory tests showed a normal blood cell count, mild anemia (hemoglobin $127 \mathrm{~g} / \mathrm{L}$, normal $>133$ ), normal hepatic and renal functions, and negative $C$-reactive protein. Serologies for herpesviridae, human immunodeficiency virus, and viral hepatitis $(A, B, C)$ were negative. Lymphocytes subpopulation count revealed low CD4+ count $\left(83\right.$ cells $/ \mathrm{mm}^{3}$, normal $\left.490-1,640\right)$ and B-cells $\left(29 / \mathrm{mm}^{3}\right.$, normal $\left.80-490\right)$.

\section{Questions for consideration:}

1. To which brain regions would you localize the symptoms?

2. What is your differential diagnosis for the origin of the visual alteration?

3. What diagnostic tests would you perform?

\section{GO TO SECTION 2}




\section{Section 2}

On clinical examination, the patient was completely blind with preserved pupillary reflex and absent optokinetic nystagmus. Complete blindness may result from a bilateral lesion of the retina, visual pathway, or visual cortex. Any lesion anterior to the geniculate body (retina, optic nerve, optic chiasma, optic tract) usually produces a defect of the pupillary reflex in addition to the visual loss, because afferent fibers travel from the retina along the optic nerve, chiasma, and optic tract, where, instead of entering the lateral geniculate body, they turn toward the midbrain and synapse in the pretectal area. ${ }^{1}$

In our patient, the intact pupillary light reflex ruled out pathology of the visual pathway anterior to the lateral geniculate body. Lesions of the lateral geniculate body are usually unilateral and produce characteristic visual field defects such as sectoranopia. Optic radiations are spread over a broad area within the white matter of the temporal, parietal, and occipital lobes; therefore complete lesion of this structure producing total blindness without other deficits is unlikely. Hence, the complete blindness in our patient was most likely a consequence of a bilateral dysfunction of the primary visual cortex, and the complex alteration of visual perception preceding the blindness suggests initial dysfunction of the nearby associative visual cortex. The absence of optokinetic nystagmus ruled out psychogenic blindness.

Considering the location of the neurologic deficit, its acute onset, and the rapid deterioration, a vertebrobasilar stroke (with recurrent embolism in the posterior cerebral arteries territories or a critical stenosis with unstable hemodynamics) should be excluded first, even in the absence of vigilance alteration or brainstem symptoms. Given the initial positive visual symptoms (vision of colors), occipital lobe seizures should be considered, and, in the context of immunosuppression, the differential diagnosis should also include infectious encephalitis (herpetic, progressive multifocal leukoencephalopathy). Because the patient was previously treated with chemotherapy and had hypertension on
Figure Acute brain MRI

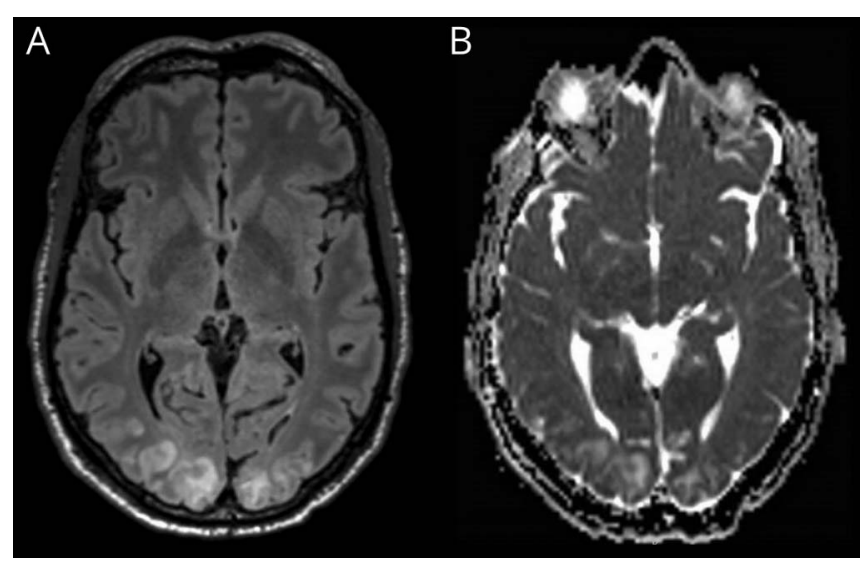

Acute brain MRI showed bilateral, mainly subcortical hyperintensity on T2-fluid-attenuated inversion recovery sequences (A), with a corresponding increase in water diffusivity as seen on the apparent diffusion coefficient map (B).

admission, a posterior reversible encephalopathy syndrome (PRES) should be similarly thought out.

Brain MRI revealed bilateral, mainly subcortical hyperintensities of occipital lobes with increased water diffusivity in diffusion-weighted sequences on T2-weighted sequences (figure). This was consistent with vasogenic edema and ruled out an acute ischemic stroke. Brain MRI angiography was normal.

Lumbar puncture showed normal cell counts and protein and glucose levels. Viral PCR from CSF (including JC virus) were negative.

The EEG was normal 2 days after admission.

\section{Question for consideration:}

1. What is the most likely diagnosis?

GO TO SECTION 3 


\section{Section 3}

Given the typical MRI findings of white matter vasogenic edema in posterior brain areas and having excluded the alternative hypotheses, our diagnosis was PRES.

The clinical evolution supported this hypothesis as the patient regained normal visual acuity within 12 hours of hospital admission. Seeing the favorable clinical evolution, repeated MRI was not deemed necessary to confirm the PRES diagnosis. Subsequent neuro-ophthalmologic examination showed normal visual acuity and normal performance in Ishihara Table recognition.

Nevertheless, before full recovery, the patient reported some new visual symptoms, lasting a further 48 hours. On day 2 after admission, he first described loss of movement vision; he could typically see people who stood still but lost sight of them when they moved and would see them again once they stopped moving. In addition, he saw residual images, seen as impressions or holograms left behind by the moving person, and during examination with Ishihara Tables, saw the colored dots projected onto the doctor's face. Later that day, during a friend's visit, he saw the face of his friend as if it was printed on the ceiling, inverted by $90^{\circ}$. Finally, while going to the toilet, he could not recognize objects reflected in the mirror, but saw instead a network of indistinguishable superimposed lines.

\section{Questions for consideration:}

1. How would you interpret the complex visual symptoms, which preceded and followed the blindness?

2. In which brain structure is the dysfunction localized for each symptom?

GO TO SECTION 4 


\section{Section 4}

Among the symptoms that preceded the loss of visual acuity, the vision of discomposed colors projected in the lower left visual field may be explained as either a seizure or a hyperexcitability following cortical deafferentation of the associative visual cortex, perhaps from the spreading of the vasogenic edema at the onset of PRES. The second explanation is more likely, given the nonstereotyped character of the symptoms and their duration. Here, the symptoms mainly concerned perturbation of color perception, a function that is localized in the lingula and fusiform gyrus. ${ }^{2}$ Therefore, we considered these regions the most likely localization, as previous studies have shown correspondence between hallucinatory experiences and the functional anatomy of the occipital lobe. ${ }^{3}$

The impossibility to interpret the time on reading the alarm clock (despite correctly seeing and recognizing each of the numbers) corresponds to an associative agnosia. ${ }^{4}$ This particular deficit can be seen in lesions interrupting the occipito-ventral visual pathway or in lesions of the left anterior temporal lobe. ${ }^{5}$

The last symptom before total blindness was a difficulty localizing position in space, with a transposition "of his head inside a lamp." We interpreted this symptom as a topographic disorientation, ${ }^{4}$ which is defined as the loss of ability to navigate caused by a disorder in the egocentric spatial reference, and seen in right or bilateral posterior parietal lesions.
Concerning the symptoms described in the recovery phase, the impossibility to perceive visual motion is defined as akinetopsia, ${ }^{4}$ a symptom corresponding to a lesion of the V5 cortex of the dominant hemisphere (which includes the posterior part of the middle temporal gyrus and the adjacent portion of the occipital gyri).

The persistence or recurrence of visual images after the stimulus has been removed is defined as palinopsia (from the Greek palin = again and opsia = seeing). We interpreted our patient's symptom as visual trailing, ${ }^{6}$ a subtype of illusory palinopsia, in which the moving object "leaves behind" visual copies that persist for a few seconds. Palinopsia can follow unilateral or bilateral lesions of the occipital, parietal, or temporal lobes. The mechanism is thought to be hyperexcitability following cortical deafferentation. We explained the projection of Ishihara Table-colored dots onto the examiner's face as categorical incorporation, another subtype of palinopsia, where a pattern is "incorporated" into the next viewed image. The projection of a previously seen image (the face of the patient's friend) can also be considered a form of palinopsia. The image rotation by $90^{\circ}$ may be the same mechanism as room-tilt illusion. ${ }^{7}$

The incapacity to recognize objects as their mirror images is a rare neurologic symptom, defined as agnosia for mirror stimuli, ${ }^{8}$ with only a few cases reported in literature.

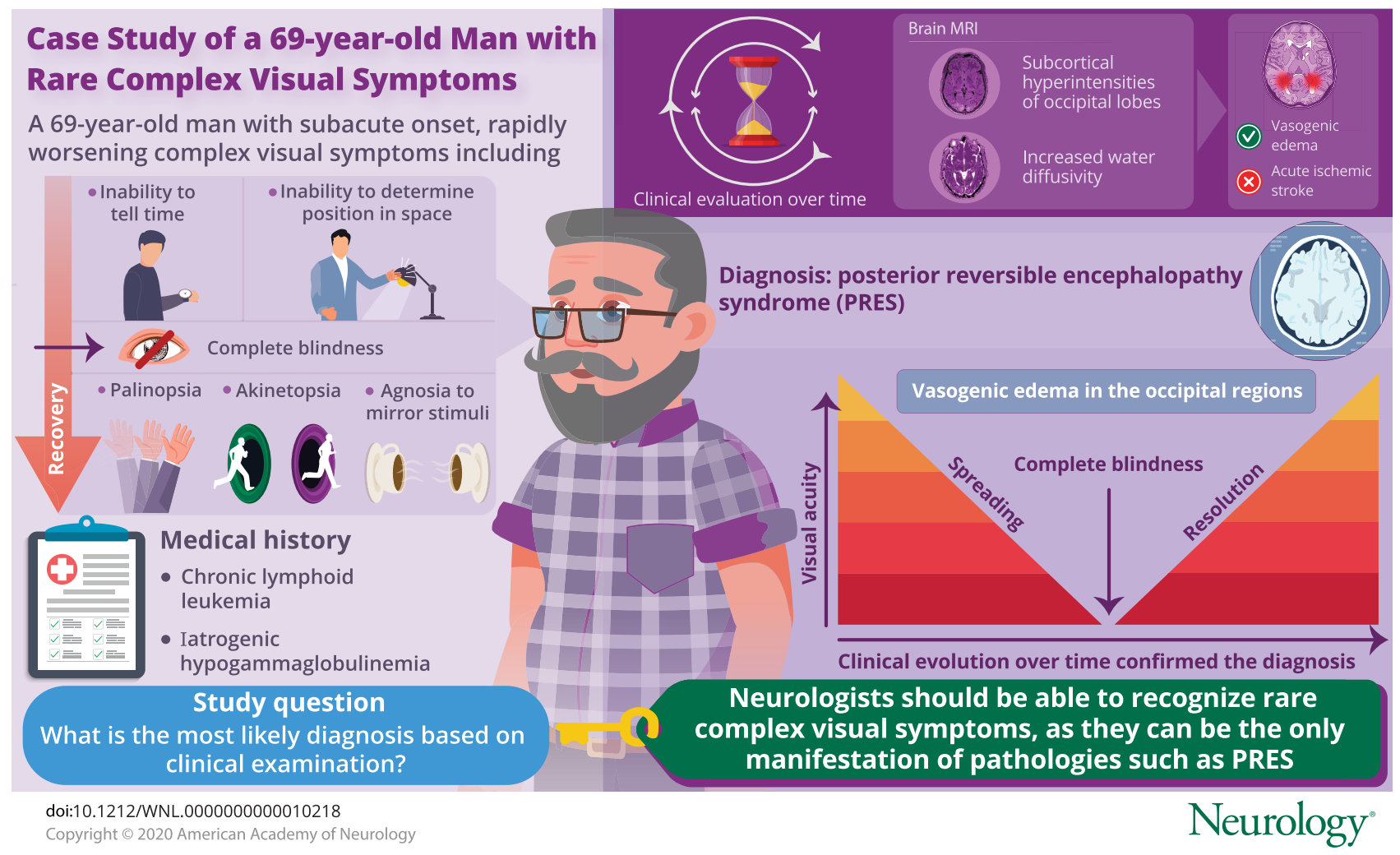




\section{Discussion}

We describe an atypical clinical presentation of PRES, showing unusual visual disturbances that rapidly evolved in time, likely reflecting first the progressive dysfunction and afterwards the gradual recovery of the different occipital areas, from the spreading and resolution of the vasogenic edema, respectively.

PRES is a condition presenting acute neurologic symptoms (mainly seizures, encephalopathy, headache, and visual disturbances), and characterized by reversible subcortical vasogenic cerebral edema in the context of renal failure, BP fluctuations, chemotherapy, autoimmune disorders, preeclampsia, or eclampsia. We identified IV immunoglobulin infusion as a predisposing factor in our patient, as previously described in some case reports. ${ }^{9}$ Physiopathology of PRES involves endothelial injury from BP alterations or direct effects of cytokines on the endothelium, leading to breakdown of the blood-brain barrier and brain edema. Neuroimaging typically reveals bilateral vasogenic edema predominant in the parieto-occipital regions. The treatment comprises removing the precipitating factor and managing potential complications. PRES usually has a favorable prognosis with reversibility of clinical and neuroradiologic alterations. ${ }^{10}$

The visual symptoms generally reported in PRES are decreased visual acuity, visual field deficits, cortical blindness, or hallucinations. Our patient presented complex visual symptoms that are usually seen with occipital, parietal, or temporal lobe lesions, causing perturbation of the visual occipito-fugal networks. We can speculate that the clinical evolution of our patient having complex visual symptoms preceding and following complete blindness reflected first the progressive dysfunction and then the recovery of the visual network, following spreading and resolution of the vasogenic edema in the occipital regions.

Although rare, these symptoms and signs should be recognized by general neurologists, as they can represent the first and (rarely) only manifestation of an acute pathology like a stroke, or a slowly evolving posterior lesion.

\section{Acknowledgement}

The authors thank Professor T. Landis for critical reading of the manuscript.

\section{Study funding}

No targeted funding reported.

\section{Disclosure}

The authors report no disclosures relevant to the manuscript. Go to Neurology.org/N for full disclosures.

Appendix Authors

\begin{tabular}{lll}
\hline Name & Location & Contribution \\
\hline $\begin{array}{l}\text { Alex Vicino, } \\
\text { MD }\end{array}$ & $\begin{array}{l}\text { University of } \\
\text { Lausanne, } \\
\text { Switzerland }\end{array}$ & $\begin{array}{l}\text { Conceptualization of the clinical } \\
\text { reasoning, major role in drafting } \\
\text { and revising the manuscript for } \\
\text { intellectual content }\end{array}$ \\
\hline $\begin{array}{l}\text { Olivier } \\
\text { Rouaud, MD }\end{array}$ & $\begin{array}{l}\text { University of } \\
\text { Lausanne, } \\
\text { Switzerland }\end{array}$ & $\begin{array}{l}\text { Revision of the manuscript for } \\
\text { important intellectual content }\end{array}$ \\
\hline $\begin{array}{l}\text { Renaud Du } \\
\text { Pasquier, } \\
\text { MD }\end{array}$ & $\begin{array}{l}\text { University of } \\
\text { Lausanne, } \\
\text { Switzerland }\end{array}$ & $\begin{array}{l}\text { Revision of the manuscript for } \\
\text { important intellectual content }\end{array}$ \\
$\begin{array}{l}\text { Davide } \\
\text { Strambo, } \\
\text { MD }\end{array}$ & $\begin{array}{l}\text { University of } \\
\text { Lausanne, }\end{array}$ & Major role in manuscript drafting \\
& Switzerland & and revision for intellectual content \\
\hline
\end{tabular}

\section{References}

1. Bähr M, Frotscher M. Duus' Topical Diagnosis in Neurology: Anatomy, Physiology, Signs, Symptoms. New York: Thieme; 2019.

2. Lee HW, Hong SB, Seo DW, Tae WS, Hong SC. Mapping of functional organization in human visual cortex: electrical cortical stimulation. Neurology 2000;54:849-854.

3. Ffytche DH, Howard RJ, Brammer MJ, David A, Woodruff P, Williams S. The anatomy of conscious vision: an fMRI study of visual hallucinations. Nat Neurosci $1998 ; 1: 738-742$.

4. Martinaud O. Visual agnosia and focal brain injury. Rev Neurol 2017;173:451-460.

5. Greene JDW. Apraxia, agnosias, and higher visual function abnormalities. J Neurol Neurosurg Psychiatry 2005;76(5 suppl):v25-v34.

6. Gersztenkorn D, Lee AG. Palinopsia revamped: a systematic review of the literature. Surv Ophthalmol 2015;60:1-35.

7. Sierra-Hidalgo F, de Pablo-Fernandez E, Herrero-San Martin A, et al. Clinical and imaging features of the room tilt illusion. J Neurol 2012;259:2555-2564.

8. Martinaud O, Mirlink N, Bioux S, et al. Mirrored and rotated stimuli are not the same: a neuropsychological and lesion mapping study. Cortex 2016;78:100-114.

9. Belmouaz S, Desport E, Leroy F, et al. Posterior reversible encephalopathy induced by intravenous immunoglobulin. Nephrol Dial Transpl 2008;23:417-419.

10. Fugate JE, Rabinstein AA. Posterior reversible encephalopathy syndrome: clinical and radiological manifestations, pathophysiology, and outstanding questions. Lancet Neurol 2015;14:914-925

\section{AAN Online Learning}

Browse a variety of online CME, self-assessment, and other learning activities to suit your wide-ranging interests and learning styles. Visit AAN.com/Learn. 


\section{Neurology}

\section{Clinical Reasoning: A 69-year-old man with rare complex visual symptoms}

Alex Vicino, Olivier Rouaud, Renaud Du Pasquier, et al.

Neurology 2020;95;316-320 Published Online before print July 30, 2020

DOI 10.1212/WNL.0000000000010218

This information is current as of July 30, 2020

$\begin{array}{ll}\begin{array}{l}\text { Updated Information \& } \\ \text { Services }\end{array} & \begin{array}{l}\text { including high resolution figures, can be found at: } \\ \text { http://n.neurology.org/content/95/7/316.full }\end{array} \\ \text { References } & \text { This article cites } 9 \text { articles, } 2 \text { of which you can access for free at: } \\ & \text { http://n.neurology.org/content/95/7/316.full\#ref-list-1 } \\ \text { Subspecialty Collections } & \text { This article, along with others on similar topics, appears in the } \\ & \text { following collection(s): } \\ & \text { All Clinical Neurology } \\ & \text { http://n.neurology.org/cgi/collection/all_clinical_neurology } \\ & \text { MRI } \\ & \text { http://n.neurology.org/cgi/collection/mri } \\ & \text { Visual processing } \\ \text { http://n.neurology.org/cgi/collection/visual_processing } & \\ & \text { Information about reproducing this article in parts (figures,tables) or in } \\ & \text { its entirety can be found online at: } \\ \text { http://www.neurology.org/about/about_the_journal\#permissions } & \text { Information about ordering reprints can be found online: } \\ \text { Permissions \& Licensing } & \text { http://n.neurology.org/subscribers/advertise }\end{array}$

Neurology ${ }^{\circledR}$ is the official journal of the American Academy of Neurology. Published continuously since 1951, it is now a weekly with 48 issues per year. Copyright @ 2020 American Academy of Neurology. All rights reserved. Print ISSN: 0028-3878. Online ISSN: 1526-632X.

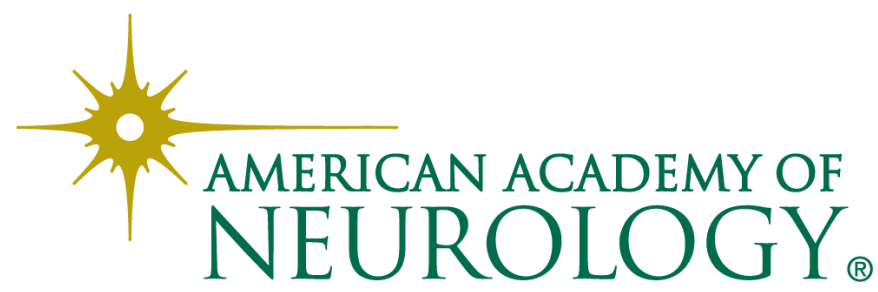

